\title{
ETYCZNE PODŁOŻE POSTAW MAKLERÓW PAPIERÓW WARTOŚCIOWYCH I DORADCÓW INWESTYCYJNYCH
}

\section{WPROWADZENIE}

1. Dyskusja o zasadności ujmowania etyki zawodowej w postać zamkniętego zbioru reguł nie zalicza się tylko do czysto teoretycznych debat, roztrząsanych w gronie odosobnionych akademików, ale odzwierciedla autentyczne dylematy, problemy i konflikty towarzyszace wykonywaniu zawodu. Jak bardzo potrzebujemy obecnie takiej dyskusji, można się przekonać nie tylko ze szczytów uniwersyteckich katedr, ale obserwując codzienną rzeczywistość, która dostarcza coraz liczniejsze i zarazem coraz bardziej dobitne przykłady na to, że standardy przyzwoitego zachowania nie stanowią wcale powszechnie znanych i respektowanych kanonów, statuujących określony wzorzec osobowy profesjonalisty. Doczekaliśmy się czasów, w których ślepa gonitwa za fachowościa, za biegłością w swoim zawodzie pobudza nas do ciagłego doskonalenia, do ustawicznej operacjonalizacji swojej efektywności, nierzadko przysłaniając to, co najbardziej fundamentalne i cenne: etos zawodu. Paradoksalnie więc, mimo coraz bardziej wydajnej pracy i coraz głębszej znajomości tajników naszej profesji, bezwiednie się zatracamy, gubiąc $\mathrm{w}$ tej pogoni cnotę i niewinność; wszak poszerzając wciąż spektrum naszych umiejętności zawodowych, ograniczamy się tylko do jednej sfery, która bynajmniej automatycznie się nie przekłada na poziom naszej wrażliwości, wyczucia dobrego obyczaju czy zwykłej uczciwości. Okazuje się, że jest wprost przeciwnie; wynosząc na piedestał skuteczność i większą konkurencyjność ogołacamy się z subtelnej wrażliwości etycznej, która niczym wewnętrzna busola wskazuje słuszny kierunek postępowania i wyznacza nasze decyzje w konkretnych sytuacjach; w razie zaś jej braku zwodzi nas na bezdroża moralnej atrofii, gdzie nawet najmądrzejsze i najbardziej opasłe księgi uczonych nie pozwalają na uzyskanie oczekiwanego standardu zachowania. Czy da się tę sytuację zmienić? Jeśli tak, to jakie zastosować tu środki, aby umocnić pożądane postawy moralne wśród przedstawicieli danej profesji?

2. Jako oczywiste jawi się tu następujące pytanie, czy warto w ogóle podejmować się rozważań na temat tak intuicyjny i nieuchwytny, jakim jest etyka określonej grupy zawodowej. Co prawda w życiu społecznym pojęcie „etyka zawodowa” zazwyczaj nie wzbudza większych wątpliwości, stwarza złudna, acz kojącą nadzieję podporządkowania - by nie rzec utożsamienia - osobistej mo- 
ralności przedstawicieli danej korporacji zawodowej standardom narzuconym przez ideały społeczne. Doświadczenie jednak uczy, że nie zawsze przekonanie to $\mathrm{w}$ pełni pokrywa się z zastaną rzeczywistością. Pokutujące w świadomości wielu ludzi wyobrażenia o określonej profesji jako szlachetnej i honorowej służbie okazują się nad wyraz często fałszywym obrazem, który skrywa gorzką prawdę, tym dotkliwsza, im bardziej rozmijającą się z abstrakcyjnym czynnikiem moralnym obsadzonym bezwiednie w roli modelowego statysty. Przyjęcie takiej perspektywy nie umniejsza jednak samego sedna problemu, który w tym przypadku ogniskuje się wokół analizy upadku etycznych standardów wśród szczególnej grupy profesjonalistów związanych stosunkiem powierniczym ze swoim mocodawcą: maklerów papierów wartościowych i doradców inwestycyjnych. To właśnie w obrębie tych dwóch zawodów pokusa dopuszczenia się czynów amoralnych jest nader wysoka; wynika to w dużej mierze ze specyfiki rynku kapitałowego, który stanowi ich naturalne miejsce pracy - jest obszarem, gdzie dokonuje się transakcji opiewajacych na imponujace kwoty, a ewentualne zyski osiagane ze zręcznych spekulacji są w stanie przesłonić wszelkie obiekcje. Jednocześnie jednak bezpieczeństwo i uczciwość obrotu są najistotniejszymi przymiotami, jakimi winien odznaczać się rynek kapitałowy dla przeciętnego inwestora. Toteż jeśli rynek będzie tych właściwości pozbawiony, czeka go marginalizacja i podatność na różnego rodzaju szoki i gwałtowne wahania koniunkturalne.

Celem niniejszego opracowania jest analiza doktrynalnych spoiw infrastruktury etycznej, które winny służyć wypracowaniu i zapewnieniu właściwej postawy moralnej osobom zatrudnionym w sektorze usług finansowych na stanowisku maklera i doradcy inwestycyjnego. Zakres analizy został świadomie ograniczony do tendencji formalizacyjnych etyki oraz roli procesów kodyfikacyjnych w jej kształtowaniu z uwzględnieniem poglądów opozycyjnych; sytuacjonizmu etycznego; dzięki tym zabiegom możliwe stało się wszechstronne oświetlenie racji przemawiających za słusznością każdego z wyżej przytoczonych zapatrywań. Zarysowana problematyka osadzona została nie tylko na szerokim tle historycznych zaszłości narosłych wokół podejmowanych kwestii, lecz także stopniowego wzrostu przenikliwości konfliktu wartości, który obecnie skłania się ku relatywizacji oceny moralnej spekulacji finansowych.

\section{SPEKULACJE FINANSOWE JAKO PRZEJAW MORALNEJ NIECNOTY UCZESTNIKÓW RYNKU}

1. Od zarania dziejów spekulacja dokonywana przez poszczególne jednostki, gildie kupieckie bądź zorganizowane instytucje należała do kategorii tego typu bezecnych aktywności ekonomicznych, które wzbudzały powszechny sprzeciw i wzgardę. Aczkolwiek nie przez wszystkich uznawana była za działanie zdrożne, zasługujące na bezwzględne potępienie; w spekulacji bowiem miało swe początki wiele zawrotnych fortun, czego dowodzi choćby przykład przytoczony przez Arystotelesa ${ }^{1}$, wedle którego słów Tales z Miletu (624-546 p.n.e.), uzna-

${ }^{1}$ Arystoteles, Polityka, tłum. L. Piotrowicz, Kraków 1964, s. 30. 
wany za jednego z pierwszych filozofów cywilizacji zachodniej, pragnąc wykazać się umiejętnością szybkiego pomnażania majątku, dokonał śmiałej spekulacji, uzyskując wysoką stopę zwrotu. Dzięki wszechstronnej wiedzy z zakresu przyrody przewidział bardzo obfity urodzaj oliwek, co skłoniło go do tego, by tuż przed zbiorami przejać w całym regionie kontrolę nad prasami do ich wyciskania. Kiedy zaś w środku sezonu popyt na nie wzrósł, filozof wyzyskał krytyczne położenie producentów oleju z oliwek, zmuszając ich do wydzierżawienia pras po zawyżonych cenach. Epizod ten doskonale oddaje istotę spekulacji jako ryzykownej czynności, która obliczona jest na ponadproporcjonalny zysk ze spodziewanych zmian w cenach dóbr, w zaopatrzeniu rynku czy metodach produkcji ${ }^{2}$.

Już starożytni Rzymianie dopatrywali się w spekulacji potencjalnego źródła niebezpieczeństwa, określając przez łacińskie słowo speculator osobę pełniącą funkcję wartownika, która miała wypatrywać zagrożenia ${ }^{3}$. Natomiast tym osobom, które parały się spekulacjami finansowymi, nadawano przydomek quaestor, co oznaczało poszukiwacza zdajaccego się na łaskę bogini Fortuny; można również się spotkać ze zbiorczym określeniem tej kategorii osób jako Graeci, czyli Grecy ${ }^{4}$ (por. Graeca fides stanowiacca odpowiednik łajdackiego postępku).

W epoce wczesnego średniowiecza kultura europejska opowiadała się wyraźnie przeciw wszelkim formom faryzejskiego i nieuprawnionego zarobkowania, fetyszyzując za sprawą nauk św. Tomasza z Akwinu arystotelesowska koncepcję sprawiedliwej ceny, według której niesprawiedliwe i bezprawne jest sprzedawać drożej bądź kupować taniej, aniżeli rzecz jest warta ${ }^{5}$. Ojciec Kościoła św. Augustyn nieopanowaną żądzę zysku uznawał za jeden z trzech grzechów głównych, który obok pragnienia władzy oraz lubieżności wiódł duszę ludzką na wieczne potępienie ${ }^{6}$. W świetle założeń filozoficznych tego uczonego w państwie Bożym nie było miejsca dla lubieżników, łakomych władzy czy spekulantów. W głośnym zaś dziele De contractibus mercatorum, autorstwa dominikanina Jahannesa Nidera, znaleźć można moralizujace passusy potępiajace spekulację rynkową opierająca się na wyzysku innych i niesprawiedliwości; według przywołanego duchownego, spekulacja jest najcięższym grzechem, którego nie da się w żaden sposób odpokutować ${ }^{7}$.

2. Mimowolnemu obłaskawieniu temat spekulacji uległ z momentem powstania zaczątków giełd towarowych w Niderlandach w XVI w. (Antwerpia, 1531 r.), gdzie masowy obrót pokaźnymi ilościami najrozmaitszych dóbr wymagał specjalistycznego personelu, który był w stanie sprostać dynamice i fluktuacji sił popytu i podaży panujących na rynku. To właśnie wraz z roz-

2 J. Black, Stownik ekonomii, tłum. E. Freyberg et al., Warszawa 2008, s. 443.

${ }^{3}$ E. Chancellor, Historia spekulacji finansowych, tłum. L. Stawowy, Warszawa 2001, s. 16.

${ }^{4}$ Pewnym objaśnieniem dla zrozumienia tego zwrotu może być pokutujący wtenczas stereotyp na temat Greków.

${ }^{5}$ E. Chancellor, op. cit., 19.

${ }^{6}$ Święty Augustyn, O państwie Bożym. Przeciw poganom ksiag XXII, tłum. W. Kornatowski, Warszawa 1977, s. 346.

${ }^{7}$ J. Nider, On the Contracts of Merchants, tłum. C. H. Reeves, Norman 1966, s. 33. 
wojem giełd wykształcił się zawód maklera, który etymologicznie pochodzi od holenderskiego makelaar, co znaczy „pośrednik”. Rzecz jasna, z samą chwila nastania dla ludzkości nowego wymiaru handlu problem spekulacji wcale nie przestał istnieć, niemniej akcent do tej pory kładziony na negatywna konotację tego terminu zdaje się, że został nieznacznie przesunięty w kierunku domeny sprawczości i przedsiębiorczości, czyli bliżej zamysłowi homo oeconomicus, aniżeli absorbującego wieki ciemne homo transcendentalis.

Nie ulega wątpliwości, że wyraźnemu ożywieniu handlu w ówczesnej Europie sprzyjał dalszy rozwój giełd, wraz z którym ewoluował sam zawód maklera - jego wykonywanie wymagało coraz bardziej zaawansowanej wiedzy. W momencie wyłonienia się z meandrów przekształceń gospodarczych pierwszych giełd finansowych (co nastapiło w XVIII w.) doszło do podziału maklerów na towarowych i finansowych; w istocie jest to podział sztuczny, gdyż tak naprawdę różnicuje ich tylko przedmiot obrotu, w którym pośredniczą (w przeszłości, jak i obecnie na wielu giełdach obraca się jednocześnie towarami oraz prawami pochodnymi, które stanowia typowy instrument giełd finansowych).

Początków zawodu doradcy inwestycyjnego próżno szukać w tak odległych czasach, z których wywodzą swój rodowód maklerzy; jest to profesja o zadecydowanie krótszej tradycji, dwudziestowiecznej. Jej istnienie jest efektem coraz większego skomplikowania rynku finansowego, poczucia zagubienia jego uczestników, a także próby rozwiązania dylematu, czy makler jako pośrednik powinien doradzać. Rola doradcy wychodzi naprzeciw tym trudnościom i w zamian za stosowne wynagrodzenie wciela się on w przewodnika po zawiłościach nurtujących niewtajemniczonych adeptów rynku; cieszy się przy tym dużą wziętością i prestiżem, płynącym nie tyle z realizacji szczytnej misji przyświecającej profesji, ile ze statusu majątkowego, a raczej z samego wyobrażenia o tym statusie, do którego osiągnięcia może doprowadzić umiejętna gra na giełdzie.

3. Wiek XX odnośnie do pojmowania spekulacji finansowych nie przyniósł jakichś rewolucyjnych zmian - nadal pielęgnowano pewien nieufny sceptycyzm wobec tego zjawiska. Czołowi przedstawiciele neoklasycznej myśli ekonomicznej konsekwentnie starali się zdyskredytować ludzką skłonność do spekulacji, argumentując m.in., że znajduje ona swe źródło w zwierzęcej namiętności uragającej naturze człowieka, który gdy jej ulegnie, zrówna się z tymi straceńcami, którzy spontaniczny entuzjazm przekładają nad racjonalne oczekiwania ${ }^{9}$. Spekulanci, zdaniem Johna Maynarda Keynesa, winni być uznani za niebezpiecznych, jeśli stanowią coś więcej niż dodatek do przedsiębiorczości $^{10}$. I zaiste, trudno się $\mathrm{z}$ nim nie zgodzić, mając na względzie następstwa

${ }^{8}$ W. Kopaliński, Stownik wyrazów obcych i zwrotów obcojęzycznych, Warszawa 1967, s. 461.

${ }_{9}^{9}$ Zob. np. J. M. Keynes, Ogólna teoria zatrudnienia, procentu i pieniqdza, tłum. M. Kalecki, S. Rączkowski, Warszawa 2003, s. 295-298.

${ }^{10}$ Ibidem. 
kilku współczesnych praktyk spekulacyjnych, obejmujących swym zasięgiem niemal wszystkie dziedziny gospodarki ${ }^{11}$.

Mimo powszechnej krytycznej opinii na temat spekulacji, co w dużej mierze było i jest uzasadnione coraz rozleglejszym obszarem szkód, które w związ$\mathrm{ku}$ z rozrostem rynku finansowego moga spowodować działania spekulacyjne, warto jednak odnotować kilka pozytywnych zjawisk, które dostrzeżono. Otóż wbrew rozpowszechnionej opinii na temat spekulacji jako „amoku napędzającego chciwość" ${ }^{2}$, jak utrzymywali niektórzy, czy też realizacji „haniebnej żądzy osiagnięcia zysków kosztem swego kolegi" ${ }^{13}$, okazuje się, że operacje te posiadają kilka poważnych zalet.

Przede wszystkim podnosi się, że spekulacje w rękach tych, którzy ich dokonuja, podobnie jak ubezpieczenia, nakierowane sa na odpowiedni rozkład ciężaru transakcji między ostatecznym nabywcą a pierwotnym sprzedawca kapitału, absorbując potencjalne ryzyko, które tamci mogliby ponieść w związku z jej finalizacja; odpowiadają więc za transfer ryzyka między uczestnikami rynku, którego ci ostatni nie chcą ponosić. Podkreśla się również, że spekulacje nierzadko, a zarazem niespodziewanie dla wszystkich przyczyniają się do ogólnego pobudzenia gospodarki, która w okresie dekoniunktury w wyniku sprzężenia się wielu tego typu operacji może powrócić na ścieżkę nagłego wzrostu i średniookresowego rozwoju ${ }^{14}$.

4. Trudno zatem oprzeć się wrażeniu, że w gospodarce rynkowej typu kapitalistycznego, która obecnie dominuje na świecie, nie sposób tak kategorycznie dewaloryzować spekulacji, jak chociażby kilkaset lat temu. Bez wątpienia jednak znaczna część tych transakcji, mimo wywierania relatywnie dodatnich skutków, więcej niesie ze sobą szkód niż korzyści. Ostatni globalny kryzys w sektorze finansowym, a także drastyczny wzrost cen produktów rolnych i żywnościowych oraz surowców energetycznych na rynkach światowych dowodzą tego niezbycie, rzucając smutny cień na wybujałe ambicje spekulantów. Okazuje się bowiem, że w sferze aktywności ekonomicznej od dłuższego już czasu daje się odczuć deficyt zarządzania bazującego na wartościach etycznych; po prostu brakuje troski uczestników życia gospodarczego o skutki po-

\footnotetext{
11 Taki charakter miały w szczególności gwałtowne zwyżki cen produktów rolnych w 2011 r. czy przeprowadzone przez kartel międzynarodowych instytucji finansowych manipulacje na rynkach walutowych w latach 2008-2013 - zob. G. Krzyminiewska, Etyczne aspekty funkcjonowania rynku finansowego. Przyktad spekulacji surowcami rolnymi, „Studia Ekonomiczne” 2015, nr 210, s. 172; J. Hrynkiewicz, Interpelacja $n r 30442$ do ministra finansów $w$ sprawie działań podejmowanych przez Ministra Finansów $w$ sprawie tzw. opcji walutowych $w$ zwiazku ze stratami poniesionymi przez przedsiębiorców i dalszego zagrożenia stratami $z$ dn. 14 stycznia 2015 r., http://marszalek. sejm.pl/Sejm7.nsf/interpelacja.xsp? documentId=1ABC7 [dostęp: 20.12.2015].

${ }_{12}$ A. S. Fell, The financial crisis: Greed run amok, Financial Post, http://network.nationalpost. com/np/blogs/ fpcomment/archive/2008/04/22/the-fi nancial-crisis-greed-run-amok.aspx [dostęp: 20.12.2015].

${ }^{13}$ J. A. Ryan, The ethics of speculation, „International Journal of Ethics” 12(3), 1902, s. 335.

${ }_{14}$ Zob. A. Zawojska, Spekulacja jako forma aktywności ekonomicznej - aspekty moralne i etyczne, „Ekonomika i Organizacja Gospodarki Żywnościowej” 2010, nr 83, s. 82 i cytowana tam literatura.
} 
dejmowanych przez siebie działań, i to zarówno tych negatywnych, jak i tych pozytywnych, odznaczajacych się kolektywną korzyścią. Aby uzupełnić ten niedobór, należy rzucić wyzwanie partykularnym modi vivendi, które pozostają w rozdźwięku z naczelnymi wartościami i zasadami moralnymi - wymaga to najpierw uświadomienia, a dopiero później akceptacji tych ostatnich, nawet wtedy gdy nie zostały wprowadzone do porządku prawnego. Wątpliwość budzi jednak to, w jaki sposób ująć te normy, aby zagwarantować ich respektowanie: zamknąc je w obrębie kodeksu czy pozostawić dla nich otwartą przestrzeń?

\section{WLAŚCIWE PODEJŚCIE DO ETYKI ZAWODOWEJ, CZYLI INCIDIS IN SCYLLAM, CUPIENS VITARE CHARYBDIM*}

1. Już Platon zauważył, że istnieją ludzie do tego stopnia spętani jarzmem swej profesji, że mimo uzyskania w niej biegłości, ich dusze wciąż pozostaja małe i nieprawe ${ }^{15}$. Watpliwy status moralny przedstawicieli wielu zawodów nie dezawuuje jednak ich roli, jaką odgrywają w życiu społecznym, a nierzadko nawet nie osłabia panegirycznego szacunku, jakim się cieszą. O deklarowanych wyobrażeniach na temat poszczególnych zawodów przesądza zazwyczaj miara ich skuteczności, wymagająca nieraz posunięcia się do oszustwa, kłamstwa, naruszenia intymności ludzkiej, ba, nawet ludzkiej godności ${ }^{16}$, ponieważ o powodzeniu w wypełnianiu zawodowej misji decyduja przede wszystkim profesjonalna wiedza, długoletnie doświadczenie i sprawność, a nie zalety charakteru $^{17}$. Jeśli więc przyjąć opinię angielskiego kpiarza Bernarda Shawa, który stwierdził, że „każdy zawód jest konspiracją przeciwko laikom”, to zaiste maklerów i doradców inwestycyjnych można byłoby w tym sensie zaliczyć do najskuteczniejszych konspiratorów ${ }^{18}$. Głęboki niepokój, jaki rodzi to spostrzeżenie, wynika z prostej obserwacji: maklerzy i doradcy wykonują zawód zaufania publicznego, który narażony jest na szczególne pokusy z racji choćby ogromnej premii finansowej, którą można uzyskać wskutek amoralnych działań. Okoliczność ta niezawodnie ułatwia im otwarcie już i tak uchylonej furtki, za którą czai się moralna niecnota, skora do dalszych wolt przeciw zastanemu porządkowi etycznemu.

\footnotetext{
* Wpadasz na Scyllę, chcąc ominąć Charybdę (przyp. red.).

${ }_{15}$ A. Stöckl, J. Weingärtner, Historia filozofji w zarysie, tłum. F. Kwiatkowski, Kraków 1930, s. 58 .

16 Tak: B. Skarga, Usankcjonowanie niecnoty, „Etyka” 1994, nr 27, s. 170.

${ }_{17}$ T. Stawecki, w tym kontekście pisze o płonnej nadziei na skuteczne wdrożenie ideałów moralnych pośród takich grup zawodowych, których członkowie za podstawowy imperatyw głębszej integracji i zaangażowania uznają radykalny wzrost własnego interesu - idem, Od perfekcjonizmu moralnego do ścistych regut odpowiedzialności zawodowej: droga ku globalnej etyce prawniczej?, w: H. Izdebski, P. Skuczyński (red.), Etyka prawnicza stanowiska i perspektywy, Warszawa 2008 , s. 146 i 153.

${ }^{18}$ Zbliżony pogląd wyraża M. Bartkowiak, Etyka zawodowa maklerów papierów wartościowych i doradców inwestycyjnych, „Ruch Prawniczy, Ekonomiczny i Socjologicznych” 65, 2003, z. 3, s. 153-154; Historia zawodu maklera, Dom Inwestycyjny BRE Banku S.A., http://www.mdm.pl/ ds-server/2157?ticketSource=ui-pub [dostęp: 20.12.2015].
} 
2. Jedna $z$ trafniejszych odpowiedzi na pojawiające się $w$ tym zakresie problemy moralne wydaje się propozycja formalizacji etyki zawodowej w postaci kodeksu etycznego. Uzasadnienie przemawiajace za tym rozwiązaniem, a więc kodyfikacją norm etycznych, jest zdroworozsądkowe i zarazem utylitarystyczne; wskazuje w pierwszej kolejności, że daremna jest jakakolwiek próba waloryzowania w kategoriach dobra czy zła poczynań przedstawicieli pewnych grup zawodowych, bez poświęcenia z ich strony cząstki wolności na rzecz archimedesowego punktu oparcia, jakim jest kodeks. Czynnik ten odgrywa tu rolę autorytetu, a dostosowanie się do jego postanowień zwalnia ze stanu czujności i troski o nieustanne odpowiadanie na pojawiajace się wątpliwości. Nader często „ów »magiczny pomocnik«, podlega personifikacji: jako Bóg, jako zasada albo osoba realna [...]"19, wznosząc się na piedestał niepodzielnego władcy. W następstwie tej apoteozy odpowiedzialność za dokonane czyny staje się pojęciem w rzeczy samej nieuchwytnym, gdyż każdy z uczestników jest przekonany o tym, że ponosi ją nie on sam, a jakaś „rzeczywista władza" ${ }^{20}$. W taki oto sposób wyłania się z normatywnej nicości pole dla „rządów Nikogo”, w obrębie którego panuje bezpieczna, wolna od niepokojów moralnych ostoja ${ }^{21}$.

Następnie wskazuje się na swoistą zwodniczość ogólnych norm etycznych, które przez swą ogólnikowość i brak precyzyjnych sformułowań tworzą zbyt obszerne spektrum możliwych działań; nie zawsze jednak tak szeroko zarysowana wielość wyboru jest pożądana; w obliczu konfliktu dóbr, które w hierarchii ogólnoludzkich wartości sa uplasowane na tym samym poziomie, nie sposób jednoznacznie określić, jakiemu z nich dać pierwszeństwo. „Dzieje się tak zwłaszcza wówczas, gdy wybór nie jest wyborem między dobrem a złem, lecz pomiędzy różnymi rodzajami dobra"22. Do rozwiązania tych konfliktów nieodzowny jest kodeks, który nie dość, że uszczegółowia ogólne normy etyczne bądź kładzie na niektóre z nich szczególny nacisk, to jeszcze stratyfikuje je i umiejscawia w ramach czytelnej skali; takie rozwiąanie jest wyrazem pewnej tęsknoty za pewnością działania, zwłaszcza tam gdzie stapanie po aksjologicznym gruncie jest niezwykle mętne i grzaskie; dostosowanie się do osławionego kodeksu, czyli postępowanie w zgodzie z nim, ma zaś stan zatrwożenia odsaczyć od złogów lęku i wątpliwości i stać się rękojmią jedynego „właściwego” zachowania ${ }^{23}$.

Podnosi się także, że o ile moralność powszechna jest zorientowana na wyznaczaniu obowiązków podstawowych wspólnych dla wszystkich, o tyle etyka zawodowa oparta jest na katalogu powinności kierowanych ku ekskluzywnym grupom zawodowym, dążącym do realizacji specyficznych celów i wartości,

19 E. Fromm, Ucieczka od wolności, tłum. O. Ziemilska, A. Ziemilski, E. Wnuk-Lipiński, Warszawa 1997, s. 170.

${ }^{20}$ Tak: Z. Bauman, Nowoczesność i zagłada, tłum. F. Jaszuński, Warszawa 1992, s. 437 i 337.

${ }^{21}$ Określenie „rządy Nikogo” przywołuję za: H. Arendt, Kilka zagadnień filozofii moralnej, w: J. Kohn (red.), Odpowiedzialność i władza sqdzenia, Warszawa 2003, s. 140.

${ }^{22}$ K. Kiciński, Etyka zawodowa a kodeks, „Etyka” 1994, nr 27, s. 175.

${ }_{23}$ P. Kaczmarek, Kodeks etyki zawodowej: $w$ poszukiwaniu bezpieczeństwa moralnego $w$ czasach niepewności, w: H. Izdebski, P. Skuczyński(red.), Etyka prawnicza stanowiska iperspektywy 3 , Warszawa 2013, s. 23. 
niekiedy wręcz o charakterze supererogatoryjnym ${ }^{24}$. Toteż kodeks etyczny, będący namacalnym odzwierciedleniem tej intuicji, wcale nie zastępuje czy też nie relatywizuje norm moralności powszechniej, lecz pełni obok niej zgoła inne funkcje. Instytucjonalizuje uchybienia moralne reprezentantów poszczególnych profesji, stawiając im liczne bariery i ograniczenia. Postać kodeksu okazuje się tu nieodzowna, ponieważ jednoznacznie, w sposób sformalizowany, zakreśla dopuszczalne granice moralnego minimum, którego nie wolno przekroczyć. Czyni to, wykorzystując spójny system reguł, wartości, do którego dostosowanie się pozwala rozwiązać każdy problem, dylemat moralny. Słowem, ustanawia sui generis monizm moralny, który suponuje, że „jest tylko jedna wartość samocelowa (albo wartość sama w sobie), której wszystkie inne podporządkowane sa jako narzędzia”"25, i przyjmuje za pewnik, że „każda szczegółowa kwestia moralna może być jednoznacznie rozwiązana przez odwołanie się do owej wartości wszechobejmującej”26.

Jako uzupełnienie powyższych uwag dodaje się również, że kodeksowa postawa moralna może uchodzić za cenny element instrumentarium pedagogicznego służącego celom zawodowej socjalizacji. Zwłaszcza w profesjach o skromnej tradycji i nikłej samoświadomości nie tylko „warsztatowej”, lecz także etycznej, odwołanie się do wychowawczej funkcji kodeksu etycznego może okazać się przydatne, ponieważ mechanizmy socjalizacji normatywnej nie sa $\mathrm{w}$ nich na tyle skutecznie autoryzowane przez doświadczenie i praktykę, aby wywrzeć pożądany wpływ na wybór określonych preferencji moralnych. Tak więc tam, gdzie nie ma etosu środowiskowego, gdzie brak jest sprawdzonych wzorów, recept, sposobów rozstrzygania sytuacji konfliktowych, a także odpowiedniej kontroli środowiska zawodowego nad swoimi członkami, wdrożenie kodeksów etycznych może stanowić pewien wstępny krok w procesie doskonalenia edukacji moralnej środowiska ${ }^{27}$. Jednocześnie czyniąc z kodeksu atrybut dyscypliny wobec tych, którzy ważą się naruszyć wysłowione w nim reguły.

3. Uzasadnienie formalizacji etyki zawodowej jawi się zatem jako dość oczywiste: wykształcić przedstawicieli określonych profesji w zakresie narzuconych oczekiwań społecznych, wpływać na ich postępowanie, stworzyć zręby wewnętrznej dyscypliny i karności. Jednakże korporacje zawodowe skłonne sa do rozwijania i przyjmowania norm dopiero w reakcji na pojawiajace się problemy. Jest to więc reaktywne i ambiwalentne podejście pozbawione przewodniego kierunku i zamysłu. Niektórzy krytycy utrzymują wręcz, że takie zabiegi bardziej przypominają etyczną przebieralnię, aniżeli służą legitymizacji tego, czym tak naprawdę zajmują się ich koledzy po fachu ${ }^{28}$. To, co zazwyczaj wynika z rozprawiania o etycznych uregulowaniach, jest w najlepszym razie stylizowaną formą społecznej hipokryzji, w najgorszym zaś - służącym

${ }_{24}$ M. Środa, Argumenty za i przeciw etyce zawodowej, „Etyka” 1994, nr 27, s. 169.

${ }^{25}$ L. Kołakowski, Mała etyka, w: idem, Czy diabet może być zbawiony $i$ 27 innych kazań, Kraków 2009, s. 129.

${ }^{26}$ Ibidem, s. 130.

27 W. Pawlik, Niecnota uregulowana, „Etyka” 1994, nr 27, s. 173.

28 Tak: R. Tokarczyk, Etyka prawnicza, Warszawa 2011, s. 70. 
samemu sobie peanem na cześć profesjonalnego prestiżu. Nawet jeśli założy się użyteczność kodeksów etyki w niektórych zawodach, to trzeba przyznać, że zbyt długa koncentracja na normach jest nie tylko zdradliwa, ale i niebezpieczna. Przyjęcie bowiem takiego założenia ignoruje fakt relatywnie niskiego wpływu tych kodeksów na codzienną rutynę i głęboko zakorzenione zwyczaje. Jako nieredukowalne do samej zawartości kodeksów powinności moralne wymagają odniesienia do czegoś więcej niż pryncypialnie ufundowany czynnik zewnętrzny, który zachęca do rezygnacji z niezależności swego indywidualnego «ja» i wtopienia się w bezdeń instytucjonalnego autorytetu ${ }^{29}$. Opieranie się wyłącznie na takiej „moralnej protezie” nie pozwala w pełni racjonalizować podejmowanych działań, czyniąc z interpretatora osobę bezwolna, niezdolna do powzięcia samodzielnego osądu. Toteż długotrwałe poleganie na drobiazgowych regulacjach jakiegokolwiek kodeksu etycznego nieodmiennie prowadzi nie tylko do zaniku moralnej inteligencji, ale i utraty wolnej woli, która szukając dla siebie ujścia, wznosi wokół siebie turris eburnea.

Takie podejście do etyki zawodowej przywodzi na myśl zaprojektowany przez Jeremy'ego Benthama panoptykon, którego przewodnia idea daje się zawrzeć w ramach prostego założenia: nadzór i kontrola ponad wszystko! Jeśli wyrazimy na to zgodę, to przez sam fakt akceptacji takiego podejścia będziemy najprawdopodobniej musieli diametralnie zmienić sposób postrzegania przez nas rzeczywistości. Jeżeli oczywiście oparty był uprzednio na należycie wykształconej wrażliwości moralnej i odpowiednio „skalibrowanym” osądzie sumienia. W przeciwnym razie nie trzeba oczekiwać zmian, których brak bynajmniej nie zwiastuje nic dobrego, wskazujac raczej, że hic niger est, hunc tu, Romane, caveto ${ }^{30}$. Ilekroć bowiem zostaniemy postawieni przed wyborem określonego zachowania, to mając w pamięci powyższą prawdę, nie będziemy mogli postapić inaczej, aniżeli ulec zewnętrznemu naciskowi, który zamiast rozwijać w nas cnoty moralne, będzie dążył do ich atrofii. Toteż w obliczu niemożności jednoznacznego sprostania różnym wartościom zaangażowanym w sytuację, wobec której jakoś zachować się trzeba, zawsze tedy za niezawodne kryterium wyboru będzie nam służyć oportunistyczna uległość. A więc orientacja na doraźny skutek, który znajdzie swe uzewnętrznienie w formie poklasku „wspólnoty jednakowych"31. Jakakolwiek wtenczas próba wzniesienia się na moralna niezależność okaże się próżna, nie będąc już w stanie skutecznie przeciwstawić się kierunkowi naszego dalszego postępowania, wszak nieprzemożna chęć schronienia się w strukturach instytucjonalnych okaże się dla nas zbyt silna,

${ }^{29}$ E. Fromm podkreśla: „Osoba, która rezygnuje ze swego indywidualnego «ja» i staje się automatem, identycznym z milionem innych otaczających go automatów, nie musi już czuć się samotna i zlękniona. A jednak cena, jaką za to płaci - utrata samego siebie - jest wysoka” (op. cit., s. 47).

${ }^{30} \mathrm{~W}$ przytoczonej frazie zawarta jest przestroga przed szubrawcem, zob. Kwintus Horacjusz Flakkus, Dzieła wszystkie, t. 2, tekst łaciński do druku przygotował, wyboru przekładów dokonał, komentarzem opatrzył O. Jurewicz, Ossolineum 1988, s. 59. („To łotr - i takich łotrów strzeż się, Rzymianinie!”, tłum. J. Czubek - przyp. red.).

${ }^{31}$ Zdaniem Z. Baumana: „Atrakcyjność »wspólnoty jednakowych« polega na tym, że zapewnia ona polisę ubezpieczeniową chroniąca przed ryzykiem, którym najeżone jest codzienne życie w wieloznacznym świecie”, obiecując jednocześnie „schronienie przed niektórymi z jego najbardziej bezpośrednich i wzbudzających lęk skutków” (idem, Szanse etyki w zglobalizowanym świecie, Kraków 2007, s. 60). 
aby wyrwać się z okowów jej władztwa. Co z oczywistych względów wcześniej czy później doprowadzi nas nie tylko do znacznego spłycenia relacji międzyludzkich, lecz także przemiany nas samych z istoty społecznej - wyrażając to nieco przesadnie - w ludzki automat, zautomatyzowane curiosum skore do posłuchu i odgórnej sterowalności.

4. Nie na tym jednak rzecz powinna polegać, przeciwnie - zamiast sytuować etykę zawodową na pozycji nadzorcy, który dzierżąc w dłoni kodeks, przestrzega surowej dyscypliny i porządku, należałoby raczej rozwijać wzór etyki zdolnej do autoafirmacji samodzielnych sądów. Przesunąc akcent z faworyzowania działania wedle jednego ujednoliconego wzoru etycznego na rzecz wielu indywidualnych, sytuacyjnych wzorów etycznych ${ }^{32}$; nie zamykać się w klatce sztywnych reguł, które zamiast pobudzać do ciagłej refleksji, onieśmielaja i krępują moralny dyskurs, a także zastępują osobistą samoświadomość mechanistycznym uzgadnianiem postępowania zawodowego w celu konwencjonalnego przesądzenia o tym, co jest, a co nie jest z nim zgodne. Idea główna, której chcemy strzec, to obrona przed utrata samego siebie, sprowadzeniem, w powyżej omówiony sposób, przedstawicieli niektórych korporacji zawodowych do roli amoralnych techników, ślepo podporządkowanych profesjonalne$\mathrm{mu}$ modus viviendi. Czym innym jest bowiem tworzenie i stosowanie kodeksów etyki zawodowej, jeśli nie moralnym ubezwłasnowolnieniem? Nie jest to przecież odkrywanie jakichś mitycznych wartości tkwiących w bycie lub jakoś inaczej ukonstytuowanych w świecie ${ }^{33}$.

Tendencja zamykania etyki w obrębie stereotypowych zachowań powinna być stopniowo wypierana przez etykę sytuacji wibrujących zmiennością życia; powinna utrwalać przekonanie, że „w rzeczywistości najbardziej cenne wartości moralne powstaja w rezultacie asymetrii między powinnościa kodeksowa i roszczeniem, tj. w sytuacjach, w których ktoś decyduje się uznać za swoją powinność coś, czego mu nikt nie ma prawa jako powinność przypisać"34. Przedstawiona myśl zakłada istnienie roszczenia etycznego do samodzielnego definiowania powinności moralnych, które wyrażają się w pragnieniu antagonistycznym względem kodeksowej moralności; skoncentrowanej na beznamiętnym i pragmatycznym podporządkowaniu się zbiorowi reguł i zaleceń. „Postępowanie moralne nie ma nic wspólnego z posłuszeństwem wobec jakiegokolwiek prawa, które nadane jest z zewnątrz" ${ }^{35}$; domaga się bowiem ciagłego utrzymywania dialogu z własnym «ja», pobudzającego sumienie do nieustannego poszukiwanie tego wszystkiego, co składa się na dobrą rację moralną. Można przeto uznać, że stanowi swego rodzaju kamień lidyjski odpowiedzialnego działania, rozsądzając, które z powstałych w umyśle fenomenów świadomości należy urzeczywistnić, by postapić słusznie, które zaś bezpowrotnie odrzucić, by nie posunąć się do niegodziwości i moralnej degradacji.

\footnotetext{
${ }^{32}$ R. Tokarczyk, Etyka prawnicza, czy prawo etyczne, „Państwo i Prawo” 2005, z. 4, s. 178.

${ }^{33}$ H. Jankowski, Kilka uwag na temat etyki zawodowej, „Etyka” 1994, nr 27, s. 181-182.

${ }^{34}$ L. Kołakowski, Etyka bez kodeksu, w: idem, Kultura i fetysze. Eseje, Warszawa 2009, s. 158.

${ }^{35}$ H. Arendt, op. cit., s. 98.
} 


\section{ZAKOŃCZENIE}

W świetle powyższego wywodu za uprawniony możemy przyjąć wniosek, że we współczesnym świecie etyka w odniesieniu do wielu grup zawodowych jest czymś znacznie szerszym niż tylko skodyfikowanym zbiorem reguł ${ }^{36}$. Okazuje się, że nawet najdokładniejsze uregulowania etyczne nie są w stanie sprostać dylematom ujawniajacym się w skomplikowanej rzeczywistości, w jakiej zwłaszcza maklerom i doradcom inwestycyjnym przychodzi uprawianie ich zawodu. Moralna relatywność minionych, jak i obecnych praktyk inwestycyjnych, nierzadko z pogranicza spekulacji finansowych, uświadamia nam, że jest to działalność wymagająca pogłębionej refleksji dostosowanej do rozmaitych warunków; samo odwołanie się - za pośrednictwem kodeksu - do prawodawczego fiat $\mathrm{w}$ zakresie krystalizujacych się tu zasad uczciwego zachowania bynajmniej nie czyni jej eksplicytna - przeciwnie, niejednokrotnie zwodzi na peryferia jałowych intelektualnych dociekań. Nie da się bowiem z obszaru normowania wyizolować tylko tak wąsko zakreślonej sfery, która ograniczałaby się wyłącznie do imperatywów wypływających z nieskażonego grą interesów źródła ${ }^{37}$. Nieuchronnie prowadziłoby to do ustanawiania takich zasad i norm, które o tyle wymuszają zawodowy konformizm, o ile rozmywaja poczucie etycznego sensu; więcej czynią dla partykularnego interesu niż dla społecznej misji poszczególnych profesji.

Warto więc szukać takich rozwiązań, które nie traktują etyki zawodowej wyłacznie jako prostej sumy uregulowań prawnych, zamkniętych w obrębie jakiegoś zbioru, lecz uznaja, że prawdziwa etyka nie wyczerpuje się w zgodności z kodeksem. Już starożytni Grecy zauważyli to, wyrażając pogląd, „że prawa dotyczące cnoty moralnej sa "niepisane", nie ma ich w kodeksach" ${ }^{38}$. Akceptacja takiego zapatrywania wydaje się konieczna, aby przynieść na tym polu zamierzony efekt; wyrażający się nie tyle w podtrzymywaniu pewnego pozoru, za którym nie idą określone standardy, ile bardziej w wykształceniu w sobie zdolności do autonomicznych wyborów moralnych, dokonywanych świadomie, niezależnie od ewentualnych kar, naród czy respektu środowiska zawodowego. Można nawet zaryzykować twierdzenie, że tylko takie podejście do etyki pozwala człowiekowi w tej dziedzinie postapić krok naprzód; kładzie bowiem akcent na rozwijanie stylu praktyki, która inspiruje raczej etyczne zachowania, niż redukuje je do zestawu gotowych schematów.

mgr Mateusz Langer

Uniwersytet im. Adama Mickiewicza w Poznaniu

mlanger@amu.edu.pl

${ }^{36}$ Tak: M. Langer, Formalizacja etyki $w$ administracji finansowej rękojmiq prawidtowego gospodarowania groszem publicznym, w: M. Buszko, D. Krupa, D. Sadłakowski (red.), Perspektywa - wyzwania wspótczesnej gospodarki, t. 2, Toruń 2015, s. 202.

${ }^{37}$ I. Kant, Uzasadnienie metafizyki moralności, tłum. M. Wartenberg, Warszawa 1984, s. 40.

${ }^{38}$ W. Tatarkiewicz, Historia filozofii, t. 1, Warszawa 1970, s. 61. 


\section{THE BACKGROUND OF ETHICAL ATTITUDES OF STOCKBROKERS AND INVESTMENT CONSULTANTS}

\section{Sum mary}

This article presents the results of a study on the doctrinal and institutional binder of ethical infrastructures, developing and ensuring virtuous behaviour of professionals engaged in the financial services sector. The area of research was restricted to the trends in the codification of ethical principles, and the impact of codified ethics on the moral attitudes of individual stockbrokers or investment consultants. Although the code of ethics may not necessarily influence one's attitudes, it may at least indicate proper conduct. An emphasis was placed on explaining what implementation of ethical infrastructures could mean in practice for the associations of professionals. This issue was explored more fully based on the results of a survey of the common shortcomings accrued around the codification of professional ethics, taking into account some philosophical arguments undermining its role in resolving moral dilemmas. The whole investigation was based on the current achievements of doctrine, complementing the scientific discourse in this area. 